\title{
Reductive and Non-reductive Mechanisms of Iron Assimilation by the Yeast Saccharomyces cerevisiae
}

\author{
By E. LESUISSE* AND P. LABBE \\ Laboratoire de Biochimie des Porphyrines, Institut Jacques Monod, Université Paris 7, Tour 43, \\ 2 Place Jussieu, 75251 Paris Cedex 05, France
}

(Received 14 June 1988; revised 29 September 1988; accepted 21 October 1988)

\begin{abstract}
Iron reduction and uptake was studied in wild-type and haem-deficient strains of Saccharomyces cerevisiae. Haem-deficient strains lacked inducible ferri-reductase activity and were unable to take up iron from different ferric chelates such as $\mathrm{Fe}$ (III)-citrate or rhodotorulic acid. In contrast, ferrioxamine B was taken up actively by the mutants as well as by the wild-type strains. At a low extracellular concentration, uptake was insensitive to ferrozine and competitively inhibited by $\mathrm{Ga}$ (III)-desferrioxamine $\mathrm{B}$. Extracellular reductive dissociation of the siderophore occurred at higher extracellular concentrations. Two mechanisms appear to contribute to the uptake of ferrioxamine B by $S$. cerevisiae: one with high affinity, by which the siderophore is internalized as such and another with lower affinity by which iron is dissociated from the ligand prior to uptake.
\end{abstract}

\section{INTRODUCTION}

Iron transport in micro-organisms has been intensively studied, and most of this research has focused on the high-affinity iron uptake systems mediated by siderophores (for reviews see Winkelmann \& Huschka, 1987; Bagg \& Neilands, 1987). Secretion of siderophores in response to iron-limitation occurs in most micro-organisms including bacteria and fungi, but there are no reports of a siderophore secreted by the yeast Saccharomyces cerevisiae. Moreover, the chemical assay for the detection of siderophores (Schwyn \& Neilands, 1987) gave negative results with this yeast (Neilands et al., 1987). Nevertheless, it is well known that the use of siderophores as iron sources is not restricted to the organisms that produce them. A variety of siderophores that occur in soils may supply iron to plants either directly (receptor-mediated transport) or indirectly, after extracellular dissociation of the chelate (Crowley et al., 1987; Castignetti \& Smarrelli, 1986).

In a previous paper (Lesuisse et al., 1987), we showed that, in common with several dicotyledonous plants (Bienfait, 1985, 1987; Romheld, 1987), S. cerevisiae is able to reduce extracellular ferric chelates - including siderophores - by a membrane-bound redox system that is induced in iron-deficient conditions. We proposed that iron must be reduced to be taken up by the cells, where it is stored in vacuoles, as are other divalent cations (Raguzzi et al., 1988).

In this paper, we have re-examined the physiological role of the ferri-reductase activity in iron uptake by $S$. cerevisiae and the iron uptake mechanisms of this yeast.

\section{METHODS}

Growth conditions. The haploid strains FL100, G122 and G204 of Saccharomyces cerevisiae (Urban-Grimal \& Labbe-Bois, 1981) were grown in liquid nutrient medium in Erlenmeyer flasks with mechanical agitation at $30^{\circ} \mathrm{C}$. The composition of media was as follows (per litre of distilled water). (1) Iron-rich medium: $30 \mathrm{~g}$ glucose; $6.7 \mathrm{~g}$ yeast nitrogen base without amino acids (Difco); $1 \mathrm{~g}$ yeast extract; $30 \mathrm{mg}$ ergosterol; $2 \mathrm{ml}$ Tween $80 ; 180 \mu \mathrm{mol}$

Abbreviations: ALA, 5-aminolevulinic acid; FOB, ferrioxamine B; DFOB, desferrioxamine B. 
iron (as ferric citrate or FOB); and either $10 \mathrm{mg}$ histidine (for G204) or $10 \mathrm{mg}$ uracil (for G122). (2) Iron-deficient medium: as (1) without added iron; residual iron was removed by the method described by Nicholas (1957) before addition of $30 \mathrm{mg}$ ergosterol, $2 \mathrm{ml}$ Tween 80 and $50 \mathrm{mg}$ ferrozine. (3) Preculture medium: as (1) without added iron. When necessary (see Results) the media were supplemented with $50 \mathrm{mg} \mathrm{ALA}^{-1}$.

Culture vessels were washed with $\mathrm{HCl} / \mathrm{HNO}_{3}(3: 1, \mathrm{v} / \mathrm{v})$ and rinsed with distilled water. Sterilized medium was inoculated with $10^{6}$ cells $\mathrm{ml}^{-1}$ from a $24 \mathrm{~h}$ preculture and cells were harvested after $15 \mathrm{~h}$, in the late exponential growth phase. The cells were washed twice with distilled water and once with $50 \mathrm{~mm}$-trisodium citrate buffer, $\mathrm{pH}$ 6.5, and used the same day for experiments.

Iron compounds. The ferric complexes ${ }^{55} \mathrm{Fe}$-citrate, ${ }^{55} \mathrm{Fe}(\mathrm{OH})_{3},{ }^{55} \mathrm{Fe}-\mathrm{FOB}$ and ${ }^{55} \mathrm{Fe}$-rhodotorulic acid were prepared for uptake experiments from ${ }^{55} \mathrm{FeCl}_{3}$ (Amersham) in order to give about $78 \mathrm{MBq}(\mathrm{mg} \mathrm{Fe})^{-1}$.

Iron uptake. The washed cells were suspended at $50 \mathrm{mg}^{\text {wet }} \mathrm{wt} \mathrm{ml}^{-1}$ in $50 \mathrm{mM}$-citrate buffer, $\mathrm{pH} 6.5$, or in $50 \mathrm{mM}-$ sodium acetate buffer, pH 5.2. Radioactive iron was added after $30 \mathrm{~min}$ preincubation at $30{ }^{\circ} \mathrm{C}$ with $5 \%$ (w/v) glucose with slow magnetic stirring. Samples $(1 \mathrm{ml})$ were withdrawn at intervals and diluted $1: 1(\mathrm{v} / \mathrm{v})$ with unlabelled iron ( $3 \mathrm{~mm}$ ) on ice. The samples were washed to remove iron non-specifically bound to the cell surface, as follows: twice with $2 \%$ (w/v) EDTA in $50 \mathrm{~mm}$-citrate buffer (pH 6.5); twice with dithionite (100 mM); and once with distilled water. Radioactivity in the washed samples was measured after solubilization of the cells $(15 \mathrm{~h}$ at $50^{\circ} \mathrm{C}$ in $1 \mathrm{ml} \mathrm{NCS}$ tissue solubilizer; Amersham).

Iron reduction. Ferri-reductase activity of the washed whole cells was measured as previously described (Lesuisse et al., 1987), with $180 \mu \mathrm{M}$-ferric citrate as substrate and $5 \%(\mathrm{w} / \mathrm{v})$ glucose in $50 \mathrm{mM}$-citrate buffer, $\mathrm{pH} 6.5$.

\section{RESULTS AND DISCUSSION \\ Ferri-reductase activity of haem-deficient cells}

Whole cells of strains G122 and G204 were tested for ferri-reductase activity. Both strains lack cytochromes, have no catalase activity and do not grow on glycerol (Urban-Grimal \& Labbe-Bois, 1981). In addition to its possible deficiency in iron metabolism (Urban-Grimal \& Labbe-Bois, 1981), G122 was described as being deficient in protoporphyrinogen oxidase activity (Camadro et al., 1982). G204 is an ALA-synthase-deficient mutant which responds to exogenous ALA by recovering the wild phenotype (presence of a functional respiratory chain) of the parental strain, FL100 (Urban-Grimal \& Labbe-Bois, 1981).

As previously described (Lesuisse et al., 1987), iron-deficient conditions induced ferrireductase activity in cells with the parental phenotype (FL100 and G204 supplemented with ALA (Table 1). Basal activity (in iron-rich conditions) and induced activity (in iron-deficient conditions) were both maximal in the late exponential growth phase (not shown). In contrast, haem-deficient cells (G122 and G204) exhibited only a very low, non-inducible level of ferrireductase activity (Table 1 ). This residual activity remained unchanged during all stages of growth, either in iron-rich or in iron-deficient conditions (not shown).

From these results, we conclude that haem is involved in the development of ferri-reductase activity. The residual activity exhibited by the two haem-deficient mutant strains could be due to intracellular traces of haem not detectable by spectral analysis; indeed, it had been previously suggested that the haem mutations of these strains could be leaky to some extent (Lewis et al.,

Table 1. Ferri-reductase activity of different strains of $S$. cerevisiae grown in iron-rich or iron-deficient media

Iron reduction was measured as described in Methods. Results are means $\pm \mathrm{SD}$ of three $(a)$, five $(b)$ or nine $(c)$ experiments.

\begin{tabular}{|c|c|c|}
\hline \multirow[b]{2}{*}{ Strain } & \multicolumn{2}{|c|}{$\begin{array}{l}\text { Ferri-reductase activity } \\
{\left[\mathrm{nmol} \mathrm{h}^{-1}(\mathrm{mg} \text { wet wt })^{-1}\right]}\end{array}$} \\
\hline & Iron-rich medium & Iron-deficient medium \\
\hline 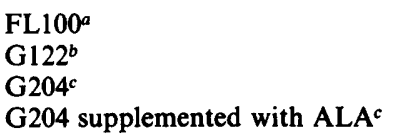 & $\begin{array}{l}3 \cdot 4 \pm 0.88 \\
0 \cdot 36 \pm 0 \cdot 2 \\
0 \cdot 39 \pm 0 \cdot 2 \\
4 \cdot 14 \pm 1 \cdot 3\end{array}$ & $\begin{array}{l}37 \cdot 2 \pm 7 \cdot 8 \\
0.54 \pm 0.2 \\
0.60 \pm 0.3 \\
40.9 \pm 9 \cdot 5\end{array}$ \\
\hline
\end{tabular}




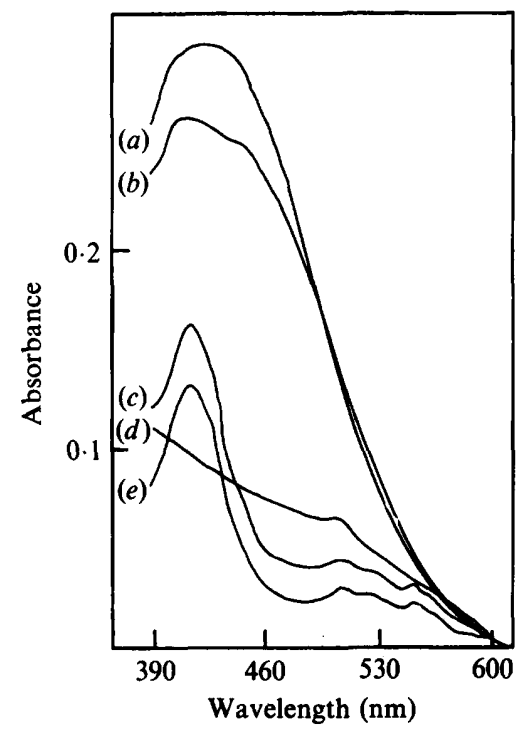

Fig. 1. Absorbance spectra of cells of strain G204 grown for $24 \mathrm{~h}$ in iron-rich medium (as ferric citrate or FOB) with or without ALA. (a) Visible spectrum of FOB $(100 \mu \mathrm{M})$ in water; $(b)$ cells grown with FOB but without ALA; (c) cells grown with FOB and with ALA; (d) cells grown with ferric citrate but without ALA; (e) cells grown with ferric citrate and with ALA. The reference cuvette contained water $(a)$ or suspension of cells of G204 grown in iron-deficient conditions without ALA $(b-e)$. Cells were suspended at $100 \mathrm{mg}$ wet $\mathrm{wt} \mathrm{ml}^{-1}$ in the sample and reference cuvettes and were previously washed once with dithionite $(100 \mathrm{~mm})$ and twice with EDTA $(2 \%, \mathrm{w} / \mathrm{v})$.

1985). In any case, the absence of significant inducible ferri-reductase activity in the haemdeficient strains made them a valuable tool for investigating the role of reduction in iron uptake.

\section{Accumulation of iron during growth}

The effect of ALA on the capacity of strain G204 to take up iron from ${ }^{55} \mathrm{Fe}$ (III)-citrate and from ${ }^{55} \mathrm{Fe}-\mathrm{FOB}$ was examined. The absence of ALA in the culture medium significantly lowered the amount of iron accumulated from ferric citrate but not from FOB : after $24 \mathrm{~h}$ growth in iron-rich medium, G204 had accumulated $268 \mathrm{pmol}$ iron (mg wet wt) ${ }^{-1}$ when FOB $(180 \mu \mathrm{M})$ was used as iron source and only 13 pmol iron (mg wet $\mathrm{wt})^{-1}$ when FOB was replaced by ferric citrate; the values were 175 and $256 \mathrm{pmol}^{(\mathrm{mg} \text { wet } \mathrm{wt})^{-1}}$ respectively when ALA was added to the culture medium (data from a single representative experiment). This indicates that reduction is not an obligatory step in iron uptake from FOB as previously suggested (Lesuisse et al., 1987). Fig. 1 shows the absorbance spectra of the washed cells after growth on iron-rich medium (as FOB or ferric citrate). As shown by the high absorbance in the range $420-440 \mathrm{~nm}$, significant amounts of FOB were accumulated without dissociation by haem-deficient cells; however, in the case of ALA-supplemented cells the ferri-siderophore was largely dissociated, probably by reduction.

\section{Iron uptake by non-growing cells}

To evaluate the relative contributions of the reductive and non-reductive mechanisms of iron assimilation, the rate of iron uptake was measured for different ferric chelates under different conditions. As shown in Table 2, iron was effectively taken up from ferric citrate, $\mathrm{Fe}(\mathrm{OH})_{3}$ or from the siderophore rhodotorulic acid only by cells with induced ferri-reductase activity (ALAsupplemented), uptake being strongly inhibited by the iron(II)-trapping reagent ferrozine. In contrast, two distinct mechanisms contributed to the uptake of iron from FOB (Table 2): at a low extracellular concentration $(7 \mu \mathrm{M})$, uptake appeared to be essentially non-reductive, as iron was accumulated not only by ALA-supplemented cells grown in iron-deficient conditions, but 
Table 2. Rate of iron uptake from different ferric chelates by cells of strain G204 grown in ironrich medium (as FOB or ferric citrate) or in iron-deficient medium, with or without ALA

Uptake experiments were done as described in Methods, except that with $\mathrm{Fe}(\mathrm{OH})_{3}$, citrate buffer was replaced with $50 \mathrm{mM}-\mathrm{MES} / \mathrm{KOH}, \mathrm{pH}$ 7. When present, ferrozine, $\mathrm{Ga}^{3+}$ as $\mathrm{Ga}\left(\mathrm{NO}_{3}\right)_{3}$ or $\mathrm{Ga}$ (III)-DFOB were added together with iron, after preincubation. The condition ' $+\mathrm{O}_{2}$ ' refers to the bubbling of oxygen through the cell suspension during the entire experiment. Results are means of five $(a)$ or three (b) experiments, or are from one experiment only $(c)$. Values in parentheses are the percentage inhibition of uptake by $1 \mathrm{~mm}$-ferrozine.

\begin{tabular}{|c|c|c|c|c|c|c|}
\hline & \multicolumn{6}{|c|}{$\begin{array}{l}\text { Iron uptake rate }\left[\mathrm{pmol} \mathrm{h} \mathrm{h}^{-1}(\mathrm{mg} \text { wet } \mathrm{wt})^{-1}\right] \text { by resting cells previously grown } \\
\text { in medium containing: }\end{array}$} \\
\hline & $A L A+F O B$ & $\begin{array}{c}\text { ALA + } \\
\text { ferric } \\
\text { citrate }\end{array}$ & $\begin{array}{l}\text { ALA (iron- } \\
\text { deficient } \\
\text { conditions) }\end{array}$ & FOB & $\begin{array}{l}\text { Ferric } \\
\text { citrate }\end{array}$ & $\begin{array}{c}\text { (Iron- } \\
\text { deficient } \\
\text { conditions) }\end{array}$ \\
\hline $\begin{array}{l}\mathrm{Fe}(\mathrm{III})-\text { citrate } \\
(7 \mu \mathrm{M})^{a}\end{array}$ & $\begin{array}{l}9.8 \\
(91)\end{array}$ & $\begin{array}{l}11 \cdot 3 \\
(95)\end{array}$ & $\begin{array}{l}59 \\
(94)\end{array}$ & $\begin{array}{l}1.2 \\
(9)\end{array}$ & $\begin{array}{l}1 \cdot 2 \\
(11)\end{array}$ & $\begin{array}{c}0 \cdot 2 \\
(0 \cdot 5)\end{array}$ \\
\hline $\begin{array}{l}\text { Fe(III)-citrate } \\
(360 \mu \mathrm{M})^{c}\end{array}$ & & $\begin{array}{l}162 \\
(99)\end{array}$ & & & & \\
\hline $\mathrm{Fe}(\mathrm{OH})_{3}(7 \mu \mathrm{M})^{c}$ & & $\begin{array}{c}0.8 \\
(100)\end{array}$ & $\begin{array}{l}6 \cdot 4 \\
(99)\end{array}$ & & $0 \cdot 2$ & 0.7 \\
\hline $\begin{array}{l}\text { Rhodotorulic acid } \\
(7 \mu \mathrm{M})^{b}\end{array}$ & & $\begin{array}{l}0.94 \\
(77)\end{array}$ & $\begin{array}{l}2 \cdot 4 \\
(82)\end{array}$ & & 0.07 & $0 \cdot 16$ \\
\hline FOB $(7 \mu \mathrm{M})^{a}$ & $\begin{array}{c}7 \cdot 2 \\
(12)\end{array}$ & $\begin{array}{l}12 \cdot 3 \\
(12)\end{array}$ & $\begin{array}{l}69 \cdot 7 \\
(27)\end{array}$ & $\begin{array}{l}60 \\
(0)\end{array}$ & $\begin{array}{c}59.4 \\
(0)\end{array}$ & $\begin{array}{l}64 \\
(0)\end{array}$ \\
\hline FOB $(7 \mu \mathrm{M})+\mathrm{O}_{2}{ }^{b}$ & & & $\begin{array}{c}37 \cdot 5 \\
(0)\end{array}$ & & & \\
\hline $\begin{array}{l}\text { FOB }(7 \mu \mathrm{M})+\mathrm{Ga}(\mathrm{III})-\mathrm{DFOB} \\
(50 \mu \mathrm{M})^{b}\end{array}$ & & $2 \cdot 8$ & $23 \cdot 5$ & & $5 \cdot 2$ & 4 \\
\hline $\begin{array}{l}\mathrm{FOB}(7 \mu \mathrm{M})+\mathrm{Ga}^{3+} \\
(50 \mu \mathrm{M})^{b}\end{array}$ & & $\begin{array}{c}9 \cdot 2 \\
(40)\end{array}$ & $\begin{array}{c}74 \\
(53)\end{array}$ & & $\begin{array}{l}61 \cdot 3 \\
(0 \cdot 2)\end{array}$ & $\begin{array}{c}63 \cdot 2 \\
(0)\end{array}$ \\
\hline FOB $(360 \mu \mathrm{M})^{b}$ & $\begin{array}{l}41 \cdot 7 \\
(60)\end{array}$ & $\begin{array}{c}62 \\
(70)\end{array}$ & $\begin{array}{l}480 \\
(79)\end{array}$ & $\begin{array}{c}113.5 \\
(0)\end{array}$ & $\begin{array}{l}127 \\
(0)\end{array}$ & $\begin{array}{l}121 \\
(2)\end{array}$ \\
\hline
\end{tabular}

also by cells grown without ALA in iron-rich or in iron-deficient media. In all cases, the inhibitory effect of ferrozine was low (0 to $27 \%$ ) and was totally suppressed if the suspension was saturated with oxygen during incubation with iron (Table 2). The contribution of the reductive mechanism to the uptake process was increased when the concentration of FOB was raised; at $360 \mu \mathrm{M}-\mathrm{FOB}$, most of the iron was taken up by the reductive mechanism in ALA-supplemented cells, as shown by the strong inhibitory effect of ferrozine (Table 2). Extracellular dissociation of FOB prior to iron uptake by $S$. cerevisiae had been previously shown by the use of ${ }^{59} \mathrm{Fe}-$ $\left[{ }^{14} \mathrm{C}\right] \mathrm{FOB}$ (Lesuisse et al., 1987).

It is interesting to note that the ferrozine-insensitive FOB transport system was induced only in iron-deficient conditions in wild-type cells but in all conditions in haem-deficient cells, even when $180 \mu \mathrm{M}$-FOB was added to the growth medium (Table 2). This observation and the fact that undissociated FOB was accumulated by mutant cells (Fig. 1) led us to hypothesize that the deficiency in ferri-reductase activity of whole cells is accompanied by a deficiency in intracellular ferri-reductase activity which may be required for the removal - and subsequent utilization - of iron from the internalized siderophore.

The mechanisms of iron uptake from FOB were further investigated by studying the effects of $\mathrm{Ga}(\mathrm{III})-\mathrm{DFOB}$ and $\mathrm{Ga}^{3+}$ on uptake. Emery \& Hoffer (1980) showed that gallium analogues of siderophores could be taken up by micro-organisms in an active transport process indistinguishable from that of ferri-siderophores. In addition, it has been demonstrated that $\mathrm{Ga}^{3+}$ can displace iron from siderophores under reducing conditions (Emery, 1986). This was confirmed for the reduction of FOB by $S$. cerevisiae: the rate of formation of the $\mathrm{Fe}$ (II)(ferrozine) $)_{3}$ complex from a cell suspension $\left(10 \mathrm{mg}\right.$ wet $\left.\mathrm{wt} \mathrm{ml}^{-1}\right)$ incubated with $200 \mu \mathrm{M}-\mathrm{FOB}$, 


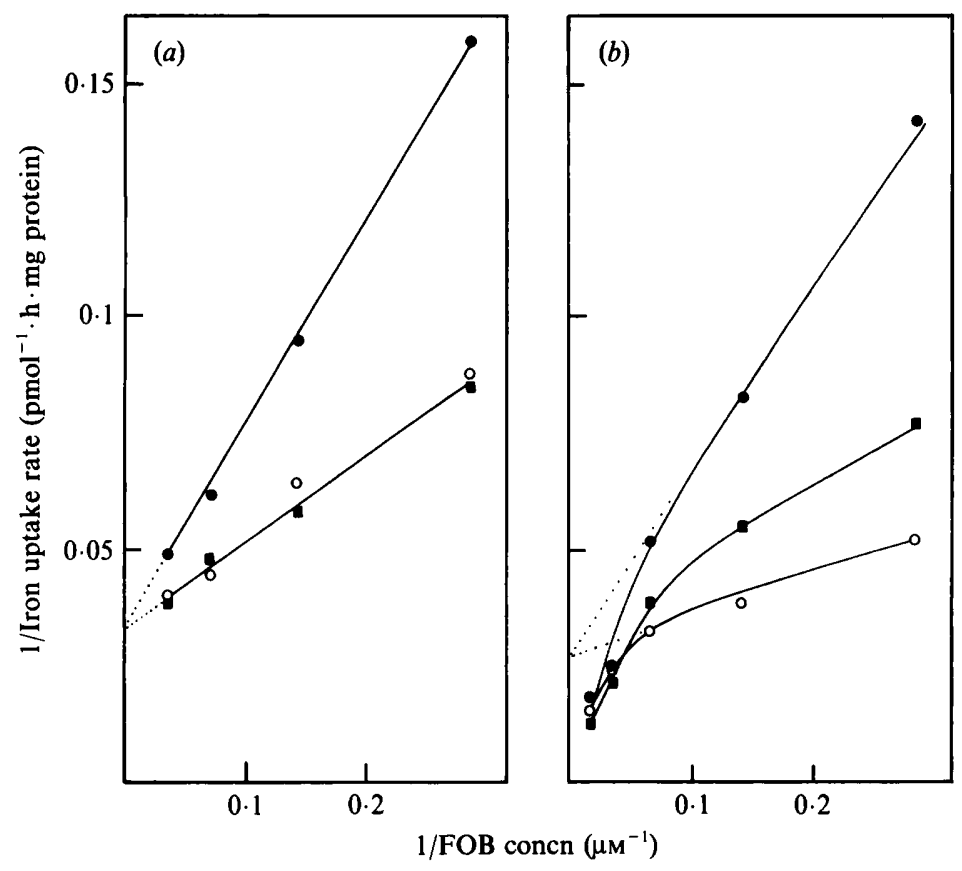

Fig. 2. Dependence on extracellular FOB concentration of the rate of iron uptake by cells of strain G204. Cells were grown in iron-deficient conditions with (a) or without (b) ALA. Uptake experiments were done in acetate buffer as described in Methods, without additions (O) or with the addition of $14 \mu \mathrm{M}-\mathrm{Ga}$ (III)-DFOB (O) or $14 \mu \mathrm{M}-\mathrm{Ga}\left(\mathrm{NO}_{3}\right)_{3}$ ( $\square$ ).

$1 \mathrm{~mm}$-ferrozine and $5 \%(\mathrm{w} / \mathrm{v})$ glucose was increased by more than $50 \%$ by the addition of $500 \mu \mathrm{M}-\mathrm{Ga}\left(\mathrm{NO}_{3}\right)_{3}$.

$\mathrm{Ga}^{3+}$ should therefore stimulate iron uptake from FOB if an essentially reductive assimilation is involved, while $\mathrm{Ga}$ (III)-DFOB should inhibit uptake in the case of a specific siderophoremediated process. Results in Table 2 show that Ga(III)-DFOB had a strong inhibitory effect on the uptake of FOB, this effect being more pronounced for haem-deficient cells. In contrast, $\mathrm{Ga}^{3+}$ had little or no effect.

Emery (1986) showed that citrate could inhibit the reductive exchange reaction between $\mathrm{Ga}^{3+}$ and FOB, and that acidic conditions were required for optimum reaction rate. Citrate buffer,

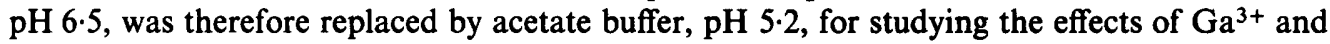
$\mathrm{Ga}$ (III)-DFOB on FOB uptake rate as a function of FOB concentration. In haem-deficient cells (Fig. $2 a$ ), uptake of FOB proceeded with apparent $K_{\mathrm{m}}$ and $V_{\max }$ values of about $5 \mu \mathrm{M}$ and $30 \mathrm{pmol} \mathrm{h}^{-1}$ (mg wet wt) $)^{-1}$ respectively $\left(V_{\max }\right.$ was 3 to 4 -fold higher in citrate buffer, at $\mathrm{pH} 6.5$; not shown). Inhibition by $\mathrm{Ga}$ (III)-DFOB was clearly competitive $\left(K_{\mathrm{i}}=10 \mu \mathrm{M}\right)$, while $\mathrm{Ga}^{3+}$ had no effect on the kinetic parameters. No simple Michaelis-Menten kinetics were obtained for the uptake of FOB by ALA-supplemented cells (Fig. $2 b$ ): below about $7 \mu \mathrm{M}$-FOB, the apparent $K_{\mathrm{m}}$ and $V_{\max }$ values were about $3 \mu \mathrm{M}$ and $37 \mathrm{pmol} \mathrm{h}^{-1}$ (mg wet wt) ${ }^{-1}$ respectively, and Ga(III)DFOB acted as a competitive inhibitor $\left(K_{\mathrm{i}}=4 \mu \mathrm{M}\right)$. As the FOB concentration was raised, deviations from Michaelis-Menten kinetics were observed, indicating that saturation could not be reached as rapidly as expected if a single high-affinity mechanism was involved. $\mathrm{Ga}^{3+}$ had a relatively low inhibitory effect, which was totally suppressed at FOB concentrations higher than $20 \mu \mathrm{M}$.

From the results in Table 2 and Fig. 2, we conclude that $S$. cerevisiae can produce a specific high-affinity transport system for FOB-type siderophores. In wild-type strains, the siderophoremediated transport system co-exists with a reductive uptake mechanism of lower affinity and specificity (Lesuisse et al., 1987), as shown by Emery (1987) for the fungus Ustilago sphaerogena. 


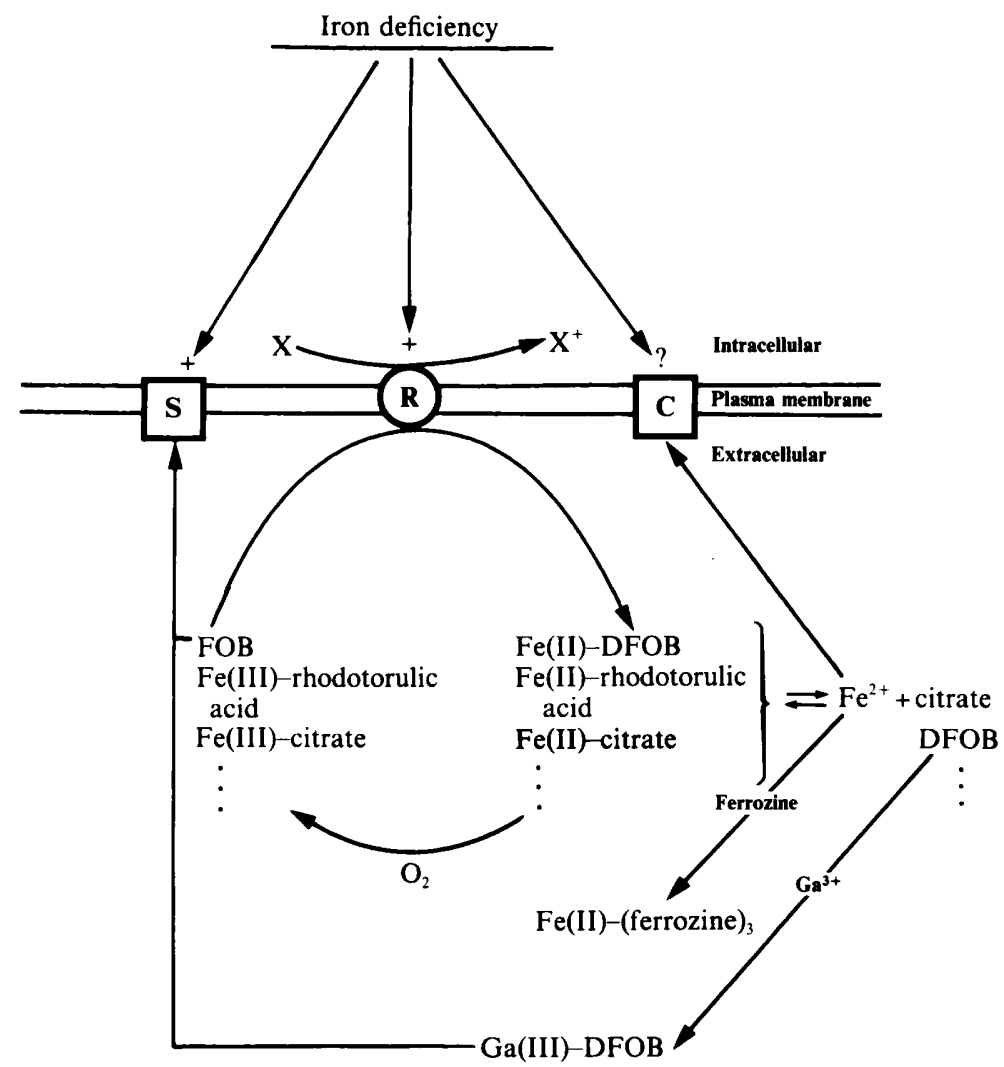

Fig. 3. Schematic representation of the mechanisms involved in iron uptake by $S$. cerevisiae. S, inducible siderophore-mediated transport system; $R$, inducible ferri-reductase ( $X$ is the intracellular electron donor); $\mathrm{C}$, divalent cation transport system.

Therefore, at low FOB concentrations, uptake occurs essentially by the high-affinity mechanism. $\mathrm{Ga}$ (III)-DFOB acts as a competitive inhibitor and $\mathrm{Ga}^{3+}$ inhibits the uptake by displacing iron from FOB; free ferrous ions are either re-oxidized or taken up by the cells via a low-affinity divalent cation uptake system $\left(K_{\mathrm{m}}\right.$ around $\left.270 \mu \mathrm{M}\right)$ (Lesuisse et al., 1987). When the FOB concentration is raised, the reductive mechanism becomes quantitatively more important as the high-affinity system approaches saturation. A model of the mechanisms involved in our uptake assays is presented in Fig. 3.

The relative efficiency of the two transport systems under iron limitation was shown by experiments in which DFOB $(20 \mu \mathrm{M})$ restored (by about $90 \%$ ) the growth yield of cells of G204 supplemented with ALA in iron-poor medium (iron $<0.1 \mu \mathrm{M}$ ); desferri-rhodotorulic acid restored the growth yield by only $22 \%$, whereas the yield was restored to $100 \%$ after addition of either $0.5 \mu \mathrm{M}$-FOB or $0.5 \mu \mathrm{M}$-ferri-rhodotorulic acid. This observation supports the view of a dual transport mechanism, one with high affinity for FOB-type siderophores and another with lower affinity for different ferric chelates including siderophores (reductive mechanism).

\section{General conclusions}

The system of iron acquisition by reductive and non-reductive mechanisms which is described here appears to be very similar to that described by Emery (1987) for $\dot{U}$. sphaerogena; in this fungus, iron can be taken up from ferrichrome and ferrichrome A (both ligands being secreted by the cells under iron-deficient conditions) either by internalization of the chelate via a 
highly specific transport system or indirectly, by means of a non-specific reductive system. The relative rate of iron uptake by the two systems depends, among other factors, on the nature of the siderophore, on its extracellular concentration and on the concentration of oxygen in the cell suspension (Emery, 1971, 1983, 1987; Ecker \& Emery, 1983). The system described here for $S$. cerevisiae differs on essentially two points. (1) $S$. cerevisiae does not itself secrete any siderophore (Neilands et al., 1987). The existence of a siderophore-mediated transport system in this fungus could therefore be considered as an 'opportunistic strategy', as found in certain plants (Crowley et al., 1987). (2) The reductive system of $S$. cerevisiae is strongly induced in iron-deficient conditions, which is not so in $U$. sphaerogena to our knowledge. This could mean that the reductive mechanism of iron assimilation is physiologically required for iron supply to $S$. cerevisiae in iron-limited conditions, as in many plants (Bienfait, 1987).

E. Lesuisse is a grantee of the Commission of the European Communities (Brussels, Belgium). This work was supported by grants from CNRS, Université Paris 7 and the Ministère de la Recherche et de l'Enseignement supérieur (MRT 510069).

\section{REFERENCES}

BagG, A. \& Neilands, J. B. (1987). Molecular mechanism of siderophore-mediated iron assimilation. Microbiological Reviews 51, 509-518.

Bienfait, F. (1985). Regulated redox processes at the plasmalemma of plant root cells and their function in iron uptake. Journal of Bioenergetics and Biomembranes 17, 73-83.

BIENFAIT, F. (1987). Biochemical basis of iron efficiency reactions in plants. In Iron Transport in Microbes, Plants and Animals, pp. 339-352. Edited by G. Winkelmann, D. van der Helm \& J. B. Neilands. Weinheim \& New York: VCH.

Camadro, J.-M., Urban-Grimal, D. \& Labbe, P. (1982). A new assay for protoporphyrinogen oxidase - evidence for total deficiency in that activity in a heme-less mutant of Saccharomyces cerevisiae. Biochemical and Biophysical Research Communications 106, 724-730.

CAstignetti, D. \& SMarrelli, J. (1986). Siderophores, the iron nutrition of plants, and nitrate reductase. FEBS Letters 209, 147-151.

Crowley, D. E., Reid, C. P. P. \& Szaniszlo, P. J. (1987). Microbial siderophores as iron sources for plants. In Iron Transport in Microbes, Plants and Animals, pp. 375-386. Edited by G. Winkelmann, D. van der Helm \& J. B. Neilands. Weinheim \& New York: VCH

ECKER, D. J. \& EMERY, T. (1983). Iron uptake from ferrichrome A and iron citrate in Ustilago sphaerogena. Journal of Bacteriology 155, 616-622.

EMERY, T. (1971). Role of ferrichrome as a ferric ionophore in Ustilago sphaerogena. Biochemistry 10, 1483-1488.

EMERY, T. (1983). Reductive mechanism for fungal iron transport. In Microbiology-1983. Edited by D. Schlessinger. Washington, DC: American Society for Microbiology.

EMERY, T. (1986). Exchange of iron by gallium in siderophores. Biochemistry 25, 4629-4633.

EMERY, T. (1987). Reductive mechanisms of iron assimilation. In Iron Transport in Microbes, Plants and Animals, pp. 235-250. Edited by G. Winkelmann, D. van der Helm \& J. B. Neilands. Weinheim \& New York: VCH.

EMERY, T. \& HoFFER, P. B. (1980). Siderophore- mediated mechanism of gallium uptake demonstrated in the microorganism Ustilago sphaerogena. Journal of Nuclear Medicine 21, 935-939.

Lesuisse, E., RAguzzI, F. \& CRICHTON, R. R. (1987). Iron uptake by the yeast Saccharomyces cerevisiae: involvement of a reduction step. Journal of General Microbiology 133, 3229-3236.

Lewis, T. A., TAylor, F. R. \& Parks, L. W. (1985). Involvement of heme biosynthesis in control of sterol uptake by Saccharomyces cerevisiae. Journal of Bacteriology 163, 199-207.

Neilands, J. B., KonopKa, K., Schwyn, B., CoY, M., Francis, R. T., PAW, B. H. \& BagG, A. (1987). Comparative biochemistry of microbial iron assimilation. In Iron Transport in Microbes, Plants and Animals, pp. 3-34. Edited by G. Winkelmann, D. van der Helm \& J. B. Neilands. Weinheim \& New York: VCH.

NichOLAS, D. J. D. (1957). Microbiological methods for determining magnesium, iron, copper, zinc, manganese and molybdenum. Methods in Enzymo$\log y 3,1035-1041$.

Raguzzi, F., Lesuisse, E. \& Crichton, R. R. (1988). Iron storage in Saccharomyces cerevisiae. FEBS Letters 231, 253-258.

ROMHELD, V. (1987). Existence of two strategies for the acquisition of iron in higher plants. In Iron Transport in Microbes, Plants and Animals, pp. 353-374. Edited by G. Winkelmann, D. van der Helm \& J. B. Neilands. Weinheim \& New York: VCH.

SchWYN, B. \& NeILANDS, J. B. (1987). Universal chemical assay for the detection and determination of siderophores. Analytical Biochemistry 160, 47-56.

URBan-Grimal, D. \& LABbE-BoIs, R. (1981). Genetic and biochemical characterization of mutants of Saccharomyces cerevisiae blocked in six different steps of heme biosynthesis. Molecular and General Genetics 183, 85-92.

WinkelmanN, G. \& HuschKa, H.-G. (1987). Molecular recognition and transport of siderophores in fungi. In Iron Transport in Microbes, Plants and Animals, pp. 317-336. Edited by G. Winkelmann, D. van der Helm \& J. B. Neilands. Weinheim \& New York: VCH. 